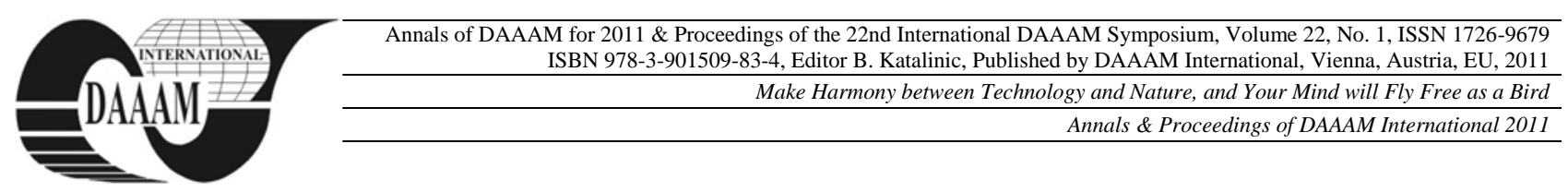

\title{
HERITAGE ASSETS IN THE ACCOUNTING OF PUBLIC INSTITUTIONS
}

\author{
CENAR, I[uliana]
}

\begin{abstract}
Under international accounting standards specific to public sector, there are provisions relating to heritage assets (concept, characteristics, recognition and presentation in the financial statements). This paper explores the legal provisions and the scientific literature to identify heritage assets at public institutions in Romania, the characteristics, their recognition and accounting implementing method.
\end{abstract}

Key words: heritage assets, public property, accounting, public institutions

\section{INTRODUCTION}

In the Romanian legal and accounting literature, there is no definition of the notion of heritage assets. Also, the size of the accounting heritage has been the subject of much controversy in literature: Olimid and Caraiani, Dutescu, Ristea and Oprea, Bojian, Ionascu etc. (quoted by Calu, 2004). The International Public Sector Accounting Standard - IPSAS 17 „Property, plant and equipment" defines and presents the characteristics of heritage assets and their accounting treatment.

Starting from these premises, we intend to provide a basis for reflection on the theoretical foundation and the accounting treatment of the heritage assets, as well as guidance, if not definitive, at least principled, into the consideration of issues raised by researchers and regulators in this field. The subject remains open to further research at least on the following issues: the subsequent recognition to initial recognition, the impairment of non-cash flows that generate assets, the broader approach in terms of accounting investigation etc.

\section{ASSETS OF PROPERTY - SEMANTICS AND CONTENT}

It is known that the asset is conceptualized by the economic resources controlled as a result of past events which are expected to generate future economic benefits or services that may be routed to the entity that it controls.

Among the meanings attributed to the concept of heritage are included the following: "all goods belonging to the community and managed by state bodies", "public goods", "spiritual goods belonging to all people (being transmitted by the ancestors)", "cultural heritage" (DEX, 1998).

Heritage is what enables the state / territorial administrative units to participate in their own name in legal relations and to assume responsibility, as a matter of law.

Even if the heritage has a wider coverage (outside of accounting), because it includes both the possibility to lack material goods and to acquire property in the future, it is subject to accounting representations, as economic values are used in the economic activity for services that meet real and rational needs existent in society (need for social security for people affected by the risk of working incapacity).

We believe that shape does not change substance and that the acquisition of the superior adaptability of accounting to the evolution of the economic environment will be the key in solving the dangerous exercise of sorting between the increased ownership of economic resources, which is specific to the heritage approach, and the control over them, emanating from the international accounting doctrine.

According to IPSAS 17 "Property, plant and equipment", heritage assets are a tangible category that has cultural, environmental or historical importance. Among the heritage assets we may include: historical buildings and monuments, archaeological sites, conservation areas and nature reserves, and works of art.

Corroborating the above issues, heritage assets could be defined as those economic resources controlled by government and territorial administrative units from which potential services are expected and which don't directly generate cash flows, but rather cultural, historical, and educational value.

The heritage comprises both cultural heritage and natural heritage that complete each other in harmony. Together, the two sub domains are the legacy that each generation leaves to its successors. In this scheme, the cultural heritage sub-domain includes the material cultural heritage - immobile heritage (historical monuments) and mobile heritage (cultural property in museums and collections) - and the intangible cultural heritage.

\section{THE PLACE OF HERITAGE ASSETS IN THE PUBLIC DOMAIN}

To identify heritage assets and their features in the Romanian public institutions, we use as a benchmark the characteristics specified in IPSAS 17 "Property, plant and equipment", namely:

- their value in cultural, environmental, educational and historical terms is unlikely to be fully reflected in a financial value based purely on a market price;

- legal and/or statutory obligations may impose prohibitions or severe restrictions on disposal by sale;

- they are often irreplaceable and their value may increase over time, even if their physical condition deteriorates;

- it may be difficult to estimate their useful lives, which in some cases could be several hundred years.

One can notice that these goods have public use, they are useful to several generations and they are managed by public institutions working in the field of culture, environment, education, history, existing prohibitions or severe restrictions related to the alienation of ownership.

In legal literature, the public domain is not perceived uniformly:

- "a set of movable and immovable goods, public property useful to all members of human communities, either directly, or through special bodies created to manage them in order to meet special needs" (I. Alexandru quoted by Bancioi\&Zaharia, 2006).

- the public domain consists of: "those goods, public or private, which by nature or express provision of law should be preserved and transmitted to future generations, representing 
values to be used in the public interest, directly or through public service, and subject to an administrative procedure, namely to a mixed regime, where the power regime is determined, being the property or in the custody of the public" (A. Iorgovan quoted by Petrescu, 2009).

the only way by which a property may be considered a public domain is the express mention of the law, and even if there are certain goods that because of their special significance should be preserved in order to be passed on to future generations and which are privately owned, it has no relevance to include those assets within the public domain, as long as the only existing way - by express declaration of the law - is not exercised (Bancioi \& Zaharia, 2006).

Thus, we can state that the object of public domain is studied and clarified in the interaction and interconditioning of the phenomena, in the accumulation of quantitative changes and their transformation through leaps in quality, in the ongoing highlighting of the struggle and of the unity of opposites.

Taking into consideration the above issues, we believe that heritage assets are an asset segment of the public domain because, according to national legislation (Law 213/1998 regarding public property and its legal status, Art. 11), public goods are inalienable, indefeasible and undetectable, namely:

- they can not be alienated, they may be given only in administration, leased or rented, in accordance with the law;

- they may not be subject to enforcement and collateral security can not be constituted upon them;

- they can not be acquired by others through usurpation or though the effect of good faith possession of movable assets.

Based on previous considerations, there can be identified a series of public goods that belong to the state / territorial administrative units, being included in the category of heritage assets, as follows: natural reserves and natural monuments, statues and monuments of national public interest, historic sites and archaeological complexes, museums, art collections declared national public interest, national parks.

The manifestation of uneven trends across the scope of the public domain is nothing more than the driving force and main content of the accounting process development, to which the complexity acquisition is attributed.

\section{IMPLEMENTING THE FINANCIAL- ACCOUNTING OF HERITAGE ASSETS}

Using as a benchmark the legal provisions of public institutions accounting, of public property and its legal system and also the provisions of IPSAS 17 "Property, plant and equipment", we believe that there are many circumstances that generate the initial recognition of heritage assets in accounting, such as: the natural progression (for natural resources); public acquisition; expropriation for public utility; donation or legacy accepted by the Government, County Council or Local Council; transferring assets from the private domain of the state or of local territorial administrative units to their public domain for reasons of public utility. Heritage assets are rarely held for their ability to generate cash inflows and there may be legal or social difficulties/ prohibitions to use them for such purposes. Generally, for these assets, the potential services are limited to their heritage characteristics. The operation and use of heritage assets is established by decision of the Government, the county council or local council and may take the following forms:

- management by the prefecture, central and local public administration authorities, other public institutions at national, county or local level.

- rental (the rental contract includes clauses to ensure exploitation of the rented property according to its specific) and the concession through public auction:

- free commissioning on a limited term to non-profit entities that run charities or public utility services, or provide public services.
According to Government Ordinance no. 81/2003, as goods that belong to the public property (which are in conservation or are part of the national cultural heritage), heritage assets are not depreciated.

Regarding the initial recognition of heritage assets, it should be noted that for a no equivalent purchase or for an insignificant value (by donation, sequestration), the cost is the fair value at the time of purchase. Also, for most of these assets, it is difficult to establish the fair value by relating to the market value because of the lack of market transactions. This can be established either by reference to items with similar characteristics, in similar circumstances and places, either by using the replacement cost method (reproduction) or the restoration cost approach (cost of reconstructing the potential service of an asset to the initial level) or service units cost approach (discounted value of the remaining possible services of the asset).

Entities that recognize heritage assets should provide information regarding those assets, such as: the used assessment base; the used depreciation method, if it exists; the gross accounting value (total); the accumulated depreciation at the end of the period; a reconciliation of the carrying amount at the beginning and end of the period, showing certain components of them. International accounting rules require the application of the disclosure provisions regarding the information on heritage assets, but leaves room for the possibility to choose their assessment.

\section{CONCLUSIONS}

Taking into consideration the purpose and content of heritage assets, the features of public property, the fact that Romanian law doesn't recognize property assets separately (at least not under this name), we may find that this category includes some of the assets that belong to the public (the State and territorial administrative units). We mention there is no uniform approach of the scope of what constitutes public goods in the legislative framework (Government Ordinance 81/2003 and Law 231/1998).

Heritage assets are assets that generate non-monetary flows, with cultural and historical value, being subject to a special legal treatment that doesn't recognize the possibility of irreversible impairment over time and that presents particularities regarding initial recognition and the recognition subsequent to the initial recognition. All these specific issues leave their mark on their accounting treatment.

\section{REFERENCES}

Albu, E. (2008) Dreptul administrativ al bunurilor, Fundation Romania de Maine Publishing, 2008, ISBN 978-973-163112-7, Bucuresti

Bancioi, C. \& Zaharia, S.A, Consideraţii privind domeniul public şi domeniul privat, Available from: http://drept.ucv.ro/RSJ/Articole/2006/RSJ4/A10BancioiZah aria.pdf, Juridical Science Review, no. 4/2006, Accessed: 2011-02-25

Calu, D.A. (2004) Patrimoniul in contabilitate: punct si... de la capat?, Contabilitatea expertiza şi auditul afacerilor Rewiev, ISSN 1454-9263, No 10, pp. 11-18, Bucuresti

IFAC. (2009). Manual de Standarde Internationale de Contabilitate pentru Sectorul Public, CECCAR Publishing, ISBN 978-973-8414-72-3, Bucuresti

Petrescu, R.N. (2009) Drept administrativ, Hamangiu, Publishing, ISBN 978-606-522-140-6, Bucuresti

Government Ordinance no. $81 / 2003$ on the revaluation and depreciation of fixed assets owned by the public institutions, Official Gazette no. 624/2003

Law no. 213/1998 on public property and its legal status, Official Gazette no. 448/1998, with the following changes 